\title{
Module development of halal consumerism education in Malaysia: a proposal
}

\begin{abstract}
Halal consumer education is growing in Malaysian context. It is driven by greater awareness among the various parties. Various programmes are offered such as awareness courses, professional courses, diploma, and degree. These include the government and private sectors. This study focuses on the proposed development of the halal consumerism education shortterm module. It encompasses three levels, i.e. preliminary, intermediate, and advanced. This course is targeted at consumer groups, industry, and the halal authority. Hence, with the offering of halal consumer education programmes, it can contribute to the understanding and awareness of halal to the halal industry players whether consumers, entrepreneurs of halal industry, or the authoritative party.
\end{abstract}

Keyword: Consumers; Entrepreneurs; Halal consumerism education; Halal haram; Halal industry 